\title{
Variation in the timing of the reproductive season among breeds of sheep in relation to differences in photoperiodic synchronization of an endogenous rhythm
}

\author{
D. O’Callaghan ${ }^{1 *}$, F. J. Karsch ${ }^{2}$, M. P. Boland ${ }^{3}$, J. P. Hanrahan ${ }^{4}$ and \\ J. F. Roche ${ }^{1}$
}

${ }^{1}$ Faculty of Veterinary Medicine, University College Dublin, Ireland; ${ }^{2}$ Reproductive Sciences Program and Department of Physiology, University of Michigan, Ann Arbor, MI 48109-0404, USA; ${ }^{3}$ Faculty of Agriculture, University College Dublin, Ireland; and ${ }^{4}$ Teagasc, Belclare, Tuam, Co. Galway, Ireland

\begin{abstract}
Summary. Photoperiod may regulate seasonal reproduction either by providing the primary driving force for the reproductive transitions or by synchronizing an endogenous reproductive rhythm. This study evaluated whether breed differences in timing of the reproductive seasons of Finnish Landrace (Finn) and Galway ewes are due to differences in photoperiodic drive of the reproductive transitions or to differences in photoperiodic synchronization of the endogenous rhythm of reproductive activity. The importance of decreasing photoperiod after the summer solstice in determining the onset and duration of the breeding season was tested by housing ewes from the summer solstice in either a simulated natural photoperiod or a fixed summer-solstice photoperiod ( $18 \mathrm{~h}$ light:6 h dark; summer-solstice hold). Onset of the breeding season within each breed did not differ between these photoperiodic treatments, but Galway ewes began and ended their breeding season earlier than Finn ewes. The duration of the breeding season was shorter in Galway ewes on summer-solstice hold than on simulated natural photoperiod; duration did not differ between photoperiodic treatments in Finn ewes. The requirement for increasing photoperiod after the winter solstice for initiation of anoestrus was tested by exposing ewes from the winter solstice to either a simulated natural photoperiod or a winter-solstice hold photoperiod $(8.5 \mathrm{~h} \mathrm{light}: 15.5 \mathrm{~h}$ dark). Onset of anoestrus within each breed did not differ between these photoperiodic treatments, but the time of this transition differed between breeds. These observations suggest that genetic differences in timing of the breeding season in Galway and Finn ewes do not reflect differences in the extent to which photoperiod drives the reproductive transitions, because neither breed requires shortening days to enter the breeding season or lengthening days to end it at appropriate times. These findings are consistent with the hypothesis that photoperiod synchronizes an endogenous rhythm of reproductive activity in both breeds and that genetic differences in timing of the breeding season reflect differences in photoperiodic synchronization of this rhythm.
\end{abstract}

Keywords: breeding season; sheep; photoperiod

\section{Introduction}

The timing of the onset and cessation of the breeding season in ewes is influenced by many factors, including photoperiod, social interactions and breed (Hafez, 1952; Wheeler \& Land, 1977; Oldham et al., 1978/1979; Quirke et al., 1986; Wayne et al., 1989). There is strong evidence that the seasonal 
reproductive transitions in certain breeds of sheep (Suffolk, Dorset Horn, Welsh Mountain) are not initiated by changes in photoperiod experienced at about the time of these reproductive transitions (Worthy \& Haresign, 1983; Robinson \& Karsch, 1984; Robinson et al., 1985; Worthy et al., 1985). The breeding season appears to begin in late summer to autumn as a result of an endogenous rhythm that is synchronized by photoperiodic cues experienced before the summer solstice. The end of reproductive activity in winter also appears to be generated by the endogenous rhythm, timed in this case by photoperiodic cues experienced before the previous autumnal equinox (Malpaux et al., 1988; Wayne et al., 1990; Woodfill et al., 1990).

Given the evidence that the seasonal reproductive transitions, at least in some breeds of sheep, result from the expression of an endogenous rhythm, it is interesting that there are marked differences among breeds in timing of reproductive transitions. Some breeds (Dorset Horn) begin their reproductive season soon after the summer solstice (Hafez, 1952). Others (Galway, Suffolk) begin at about the autumnal equinox (Hafez, 1952; Quirke \& Hanrahan, 1985; Hanrahan, 1986a; Quirke et al., 1986). Still others (Finnish Landrace (Finn), Soay) delay onset of breeding until well after the autumnal equinox (Grubb \& Jewell, 1973; Wheeler \& Land, 1977; Hanrahan, 1986b, 1990). The end of the breeding season varies from soon after the winter solstice (Suffolk ewes; Robinson \& Karsch, 1988), to near the vernal equinox (Galway ewes; Quirke et al., 1986), to near the summer solstice (Finn ewes; Wheeler \& Land, 1977; Hanrahan, 1990).

These observations prompt a number of questions related to the cause of variation among breeds in the timing of reproductive transitions. Is the variation due to genetic differences in response to the same photoperiodic signal? Is this variation due to differences in the endogenous rhythm, the degree to which it is influenced by photoperiod, or the phase relationship between the photoperiodic cycle and the rhythm in its synchronized state? Is the variation due to differences in the extent to which the endogenous rhythm is used to generate the reproductive transitions?

To begin to address these questions, we examined the extent to which photoperiod synchronizes an endogenous reproductive rhythm as opposed to exerting a driving force to induce the reproductive transitions. We used Galway and Finnish Landrace ewes as genetic models, breeds in which the reproductive seasons are offset by $6-8$ weeks. To distinguish between the importance of photoperiodic change versus the endogenous rhythm in generating reproductive transitions, we determined the requirement for decreasing photoperiod after the summer solstice to initiate the breeding season and the requirement for increasing photoperiod after the winter solstice to initiate anoestrus.

\section{Materials and Methods}

Four experiments were performed on sexually mature ewes (3-5 years old) at University College Dublin farm in Ireland $\left(53^{\circ} \mathrm{N}\right)$. Ewes were maintained indoors in light-sealed rooms under artificial photoperiod. Daylength was regulated by electronic timers operating fluorescent tubes which provided a light intensity of approximately 350 lux lateral to the head of the sheep. A dim red light, producing $<2$ lux at $1 \mathrm{~m}$ distance, was mounted $2 \mathrm{~m}$ above the sheep and was on continuously to facilitate stock inspection at night. Temperature was not regulated in the photochambers, but mean maximum and minimum temperatures recorded once per week for one year indicated that temperature extremes within the photochambers vary on an annual basis from a minimum of $10^{\circ} \mathrm{C}$ to a maximum of $28^{\circ} \mathrm{C}$; the range in temperature on a daily basis was, on average, $3^{\circ} \mathrm{C}$. Ewes were fed hay plus supplementary concentrates. Intake of concentrates was adjusted monthly to maintain body weight and condition. Water was available ad libitum.

\section{Experimental models}

Animal model. Two animal models were used in these experiments. An ovary-intact ewe was used in Expts 1-3, circulating progesterone being the indicator of reproductive activity. An ovariectomized ewe treated with oestradiol was used in Expt 4, luteinizing hormone ( $\mathrm{LH})$ being the indicator of reproductive activity. The use of two animal models was necessary because of the type of ewe available at the time of the experiment. The similarity of these two models in terms of times of seasonal reproductive transitions has been documented (Robinson \& Karsch, 1984; Karsch et al., 1989). All treatment comparisons were made as groups containing the same animal model. Studies were performed on adult purebred Galway and Finn ewes. 
The times of reproductive transitions in ewes on natural photoperiod were determined by maintaining ovaryintact Galway $(n=7)$ and Finn $(n=7)$ ewes and ovariectomized Galway ewes treated with oestradiol $(n=6)$ at Teagasc Research Station, Belclare, Co. Galway $\left(53^{\circ} \mathrm{N}\right)$. Times of reproductive transitions between spring 1987 and spring 1988 were determined by measurement of concentrations of progesterone in blood from ovary-intact ewes and LH in blood from ovariectomized ewes. Blood samples were collected once per week.

Photoperiodic model. The role of an endogenous rhythm in generating seasonal reproductive transitions and in determining the length of the breeding season was tested in a 'summer-' or 'winter-solstice hold' photoperiodic model (Robinson \& Karsch, 1984; Robinson et al., 1985). In this model, ewes were moved indoors at a solstice and maintained at the photoperiod of that solstice (summer- or winter-solstice hold). The timing of the reproductive transitions was compared with those of ewes moved indoors on a solstice and exposed to photoperiodic changes that mimicked contemporary changes outdoors (simulated natural photoperiod). The assumptions of this model are as follows: if the next reproductive transition is unaffected by exposure to a solstice-hold photoperiod, the transition is considered not to be driven by the photoperiod prevailing at that transition, but to be generated endogenously and timed by photoperiod experienced before that solstice. In contrast, if timing of this reproductive transition is delayed (or does not occur at all) in animals maintained on a solstice-hold photoperiod, the transition is considered to be driven by the change in photoperiod at the time of the transition. Further, if the breeding season is shortened by maintaining ewes in the summer-solstice hold photoperiod, the decrease in daylength after the summer solstice is considered to be necessary to sustain reproductive activity. If it is not shortened, the endogenous rhythm in itself is considered sufficient to generate a breeding season of normal duration.

\section{Role of decreasing photoperiod in onset and duration of the breeding season}

Experiment 1: Finn ewes. Eighteen ovary-intact Finn ewes were moved from natural photoperiod to light-sealed photochambers on the summer solstice (1988) and maintained on artificial photoperiod until the end of the following breeding season. Ewes were allocated at random to the following photoperiod treatments: (i) simulated naturalphotoperiod was initially equivalent to that of the summer solstice ( $18 \mathrm{~h}$ light:6 $\mathrm{h}$ dark; lights on at $05: 30 \mathrm{~h}$ GMT) and thereafter was adjusted twice per week to mimic natural changes in photoperiod $(n=9)$; (ii) summer-solstice hold photoperiod of the summer solstice was maintained throughout $(n=9)$. The photoperiods used were based on times of sunrise and sunset in Dublin $\left(53^{\circ} \mathrm{N}\right)$, with the light period extended by $30 \mathrm{~min}$ at both dawn and dusk to accommodate civil twilight. Light intensity was not altered during these $30 \mathrm{~min}$. Such adjustments have been found appropriate for sheep (Malpaux et al., 1988). Light timers were set to the nearest minute and, for ewes on simulated natural photoperiod, times of both dawn and dusk were altered to produce the appropriate photoperiod. Reproductive activity was assessed by measurement of serum progesterone concentrations in blood samples collected once a week.

Experiment 2: Galway ewes. Fifteen ovary-intact Galway ewes were moved from natural photoperiod to lightsealed photochambers on the summer solstice (1987) and allocated to the following photoperiod treatments: (i) simulated natural $(n=8)$; (ii) summer-solstice hold $(n=7)$. Ewes were treated as in Expt I, except that simulated natural photoperiod was adjusted once per week. Reproductive activity was assessed as for Expt 1 .

\section{Role of increasing photoperiod in onset of anoestrus}

Experiment 3: Finn ewes. Eighteen ovary-intact Finn ewes were moved to light-sealed photochambers on the summer solstice (1988) and maintained on a natural simulated photoperiod as in Expt 1 . They were allocated at random to the following photoperiod treatments on the subsequent winter solstice: (i) simulated natural-photoperiod

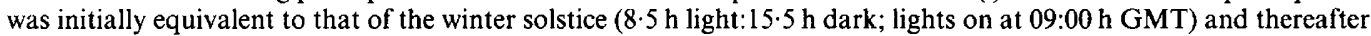
adjusted twice per week to mimic natural changes in photoperiod in Dublin $(n=9$; same animals as simulated natural group of Expt 1); (ii) winter-solstice hold - photoperiod of the winter solstice was maintained $(n=9)$. Reproductive activity was assessed as for Expt 1.

Experiment 4: Galway ewes. Twenty Galway ewes were moved to light-sealed photochambers on the winter solstice (1986) and allocated to photoperiod treatments as follows: (i) simulated natural $(n=6)$; (ii) winter-solstice hold $(n=14)$. Ewes were treated as in Expt 3, except that simulated natural photoperiod was adjusted once per week. Two months after reproductive activity had ended (April 1987), the group of ewes held on winter-solstice photoperiod was subdivided into the following two treatments to investigate the role of long days in synchronizing reproductive onset: (i) winter-solstice hold - ewes were maintained on the winter-solstice photoperiod $(n=5)$; (ii) interrupted winter-solstice photoperiod - ewes were exposed to 35 days of summer-solstice photoperiod from 20 April and then returned to the winter-solstice photoperiod $(n=7)$. The remaining two ewes held on winter-solstice photoperiod were excluded from this part of the experiment for health reasons. Reproductive activity was monitored until January of the following year (1988). Each ewe was ovariectomized and treated subcutaneously with a Silastic capsule filled with a $30 \mathrm{~mm}$ column of oestradiol before the onset of the experiment (Karsch et al., 1973). Reproductive activity was assessed by monitoring concentrations of LH in serum from blood samples collected twice per week. 


\section{Assays}

Progesterone concentrations were determined in duplicate aliquots $(50 \mu l)$ of unextracted serum by the radioimmunoassay of Ronayne \& Hynes (1990). Interassay coefficient of variation (CV) for three serum pools containing $0 \cdot 2,2 \cdot 1$ and $4 \cdot 7 \mathrm{ng} \mathrm{ml}^{-1}$ averaged $11 \cdot 6,2 \cdot 0$ and $3.5 \%$, respectively. Intra-assay CV for the same serum pools were $8 \cdot 4$, 1.4 and $3.7 \%$, respectively. The sensitivity of the assay (minimum level different from zero) was $0.05 \mathrm{ng} \mathrm{ml}^{-1}$.

Concentrations of LH were determined in duplicate aliquots $(25-200 \mu \mathrm{l})$ of unextracted serum using the radioimmunoassay of Niswender et al. (1968, 1969), as modified by Hauger et al. (1977). Values are expressed in terms of NIAMDD-oLH-24. Interassay CV for three serum pools containing $0 \cdot 4,1 \cdot 0$ and $2 \cdot 3 \mathrm{ng} \mathrm{ml}^{-1}$ was $12 \cdot 3,4 \cdot 8$ and $5 \cdot 2 \%$, respectively. Intra-assay $\mathrm{CV}$ for the same serum pools was $10 \cdot 8,3 \cdot 5$ and $3.2 \%$, respectively. Sensitivity of the assay was $0 \cdot 2 \mathrm{ng} \mathrm{ml}^{-1}$.

\section{Data analysis}

Onset of reproductive activity in ovary-intact ewes was defined as the date of the first progesterone value $>0.5 \mathrm{ng}$ $\mathrm{ml}^{-1}$ in a series of two or more consecutive samples $>0.5 \mathrm{n} \mathrm{ml}^{-1}$, or one sample $>1.0 \mathrm{ng} \mathrm{ml}^{-1}$. End of reproductive activity was defined as the date of the last progesterone value $>0.5 \mathrm{ng} \mathrm{ml}^{-1}$ in a series of two or more samples $>0.5 \mathrm{ng} \mathrm{ml}^{-1}$, or the last sample $>1.0 \mathrm{ng} \mathrm{ml}^{-1}$, followed by four or more consecutive samples $<0.5 \mathrm{ng} \mathrm{ml}^{-1}$. The profiles of circulating progesterone typically observed and times of reproductive transitions for Galway ewes exposed to simulated natural photoperiod in Expt 2 are illustrated (Fig. 1a).

(a)

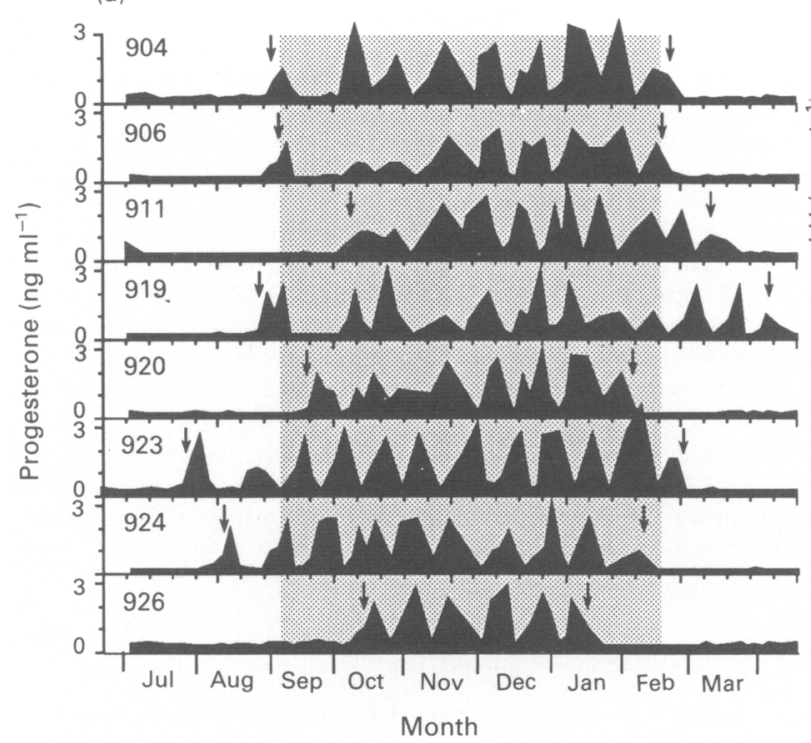

(b)

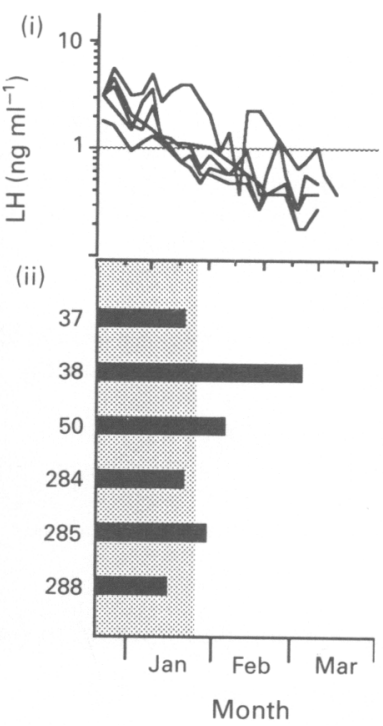

Fig. 1. (a) Serum progesterone concentrations in eight numbered Galway ewes (Expt 2) exposed to simulated natural photoperiod from the summer solstice. Shaded area shows time between mean date of onset and end of the period of reproductive activity. Arrows indicate times of onset and end of reproductive activity in individual ewes. (b) Patterns of serum luteinizing hormone (LH) in ovariectomized Galway ewes (Expt 4) treated with continuous-release oestradiol capsules, in simulated natural photoperiod from the winter solstice; (i) values of individual ewes plotted on a logarithmic scale, (ii) the period of high LH in each ewe (represented by thick black bar). Shaded area depicts time before mean date of the end of the neuroendocrine breeding season.

In ovariectomized ewes treated with oestradiol (Expt 4), serum LH values $>1.0 \mathrm{ng} \mathrm{ml}^{-1}$ were taken as indicating the neuroendocrine breeding season, as described by Robinson \& Karsch (1984). The date when LH fell to values consistently $<1.0 \mathrm{ng} \mathrm{ml}^{-1}$ was considered the onset of the neuroendocrine anoestrous season. The profiles of circulating LH typically observed in our study and the time of transition to anoestrus for Galway ewes exposed to simulated natural photoperiod in Expt 4 are illustrated in Fig. Ib.

Dates of transfer from one reproductive state to the next were analysed using Kruskal-Wallis and Mann-Whitney non-parametric U tests (Siegel, 1956). Values were considered different at a significance level of $P<0.05$. 


\section{Results}

The time of onset of anoestrus in spring 1987 or 1988 and onset of the breeding season in autumn 1987 (Table 1) was not different in ovary-intact or oestradiol-treated ovariectomized Galway ewes $(P>0.05)$. In ovary-intact ewes, onset of anoestrus in spring 1987 or 1988 and onset of the breeding season in autumn 1987 was earlier in Galway than in Finn ewes $(P<0.01)$. The breeding season in Finn ewes tended to be longer than in Galway ewes (Table $2 ; P<0.06$ ).

Table 1. Date ( \pm SEM in days) of the onset of anoestrus in spring 1987 , onset of the breeding season in autumn 1987 and onset of anoestrus in spring 1988 in ovary-intact Galway $(n=7)$ and Finn ewes $(n=8)$ and in ovariectomized Galway ewes treated with oestradiol $(n=6)$

\begin{tabular}{|c|c|c|c|c|}
\hline & & $\begin{array}{c}\text { Onset anoestrus } \\
1987\end{array}$ & $\begin{array}{l}\text { Onset breeding } \\
\text { season } 1987\end{array}$ & $\begin{array}{c}\text { Onset anoestrus } \\
1988\end{array}$ \\
\hline $\begin{array}{l}\text { Galway } \\
\text { Galway }\end{array}$ & $\begin{array}{l}\text { Ovary-intact } \\
\text { Ovariectomized }\end{array}$ & 28 March $\pm 13^{\mathrm{a}}$ & 21 September $\pm 3^{\mathrm{a}}$ & 22 March $\pm 12^{\mathrm{a}}$ \\
\hline Finn & $\begin{array}{l}\text { +oestradiol } \\
\text { Ovary-intact }\end{array}$ & $\begin{array}{l}22 \text { February } \pm 16^{\mathrm{a}} \\
13 \text { May } \pm 3^{\mathrm{b}}\end{array}$ & $\begin{array}{l}7 \text { September } \pm 13^{\mathrm{a}} \\
8 \text { October } \pm 6^{b}\end{array}$ & $\begin{array}{l}7 \text { April } \pm 24^{\mathrm{ao}} \\
17 \text { May } \pm 14^{\mathrm{b}}\end{array}$ \\
\hline
\end{tabular}

${ }^{a, b}$ Means within columns with different superscripts are significantly different $(P<0.01)$.

Table 2. Duration of the breeding season ( \pm SEM) in Galway and Finn ewes maintained on different photoperiods

\begin{tabular}{|c|c|c|c|c|}
\hline Breed & $n$ & Photoperiod & $\begin{array}{l}\text { Breeding season } \\
\text { duration } \\
\text { (days) }\end{array}$ & $\begin{array}{c}\text { Difference } \\
\text { between breeds } \\
P\end{array}$ \\
\hline $\begin{array}{l}\text { Galway } \\
\text { Finn }\end{array}$ & $\begin{array}{l}7 \\
8\end{array}$ & Natural & $\begin{array}{l}184 \pm 12 \\
224 \pm 15\end{array}$ & $<0.06$ \\
\hline $\begin{array}{l}\text { Galway } \\
\text { Finn }\end{array}$ & $\begin{array}{l}8 \\
9\end{array}$ & Simulated natural & $\begin{array}{l}163 \pm 14 \\
154 \pm 9\end{array}$ & n.s. \\
\hline $\begin{array}{l}\text { Galway } \\
\text { Finn }\end{array}$ & $\begin{array}{l}7 \\
9\end{array}$ & $\begin{array}{l}\text { Summer solstice } \\
\text { hold }\end{array}$ & $\begin{array}{l}107 \pm 7 \\
135 \pm 11\end{array}$ & $<0.05$ \\
\hline
\end{tabular}

n.s.: not significant.

\section{Role of decreasing photoperiod in onset and duration of the breeding season}

Experiment 1: Finn ewes. Mean ( \pm SEM) date of onset of the breeding season (first ovulatory cycle) in Finn ewes maintained on simulated natural photoperiod was 23 October \pm 2 days, which was not significantly different $(P>0.05)$ from that of Finn ewes maintained on summer-solstice hold photoperiod ( 1 November \pm 8 days; Fig. 2a). The end of the breeding season in the two groups was also not significantly different (26 March \pm 10 days and 16 March \pm 7 days for ewes exposed to the natural simulated and summer-solstice hold photoperiods, respectively, $P>0 \cdot 05$ ). Duration of reproductive activity in Finn ewes exposed to the summer-solstice hold photoperiod tended to be shorter than in ewes maintained on simulated natural photoperiod, although a significant difference was not observed (Table 2; $P>0.05$ ).

Experiment 2: Galway ewes. Mean date of onset of the breeding season (first ovulatory cycle) in Galway ewes maintained on simulated natural photoperiod was 6 September \pm 8 days, which was not significantly different $(P>0.05)$ from that of Galway ewes maintained on summer-solstice 
(a)

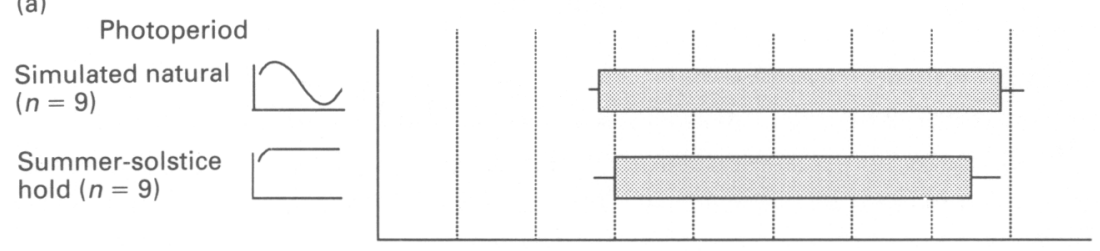

(b)

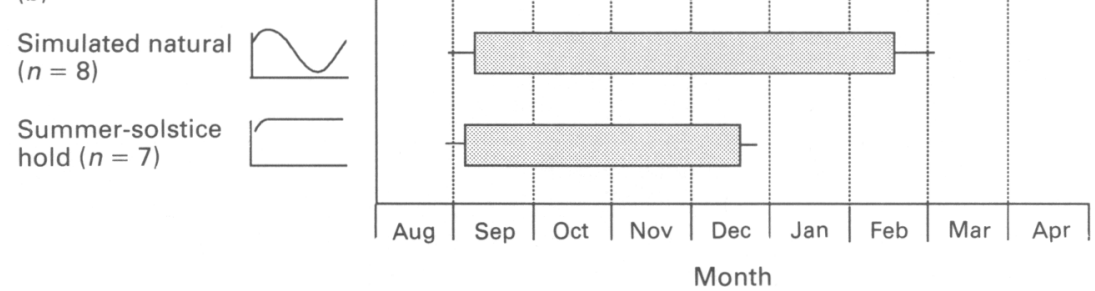

Fig. 2. Dates (mean \pm SEM) of onset and end of the breeding season (shaded bars) in (a) Finn (Expt 1) and (b) Galway ewes (Expt 2) exposed to simulated natural or summer-solstice hold photoperiod ( $18 \mathrm{~h}$ light: $6 \mathrm{~h}$ dark) from the summer solstice.

hold photoperiod ( 3 September \pm 6 days; Fig. $2 b$ ). The end of the breeding season, however, differed between groups, being later in ewes exposed to the simulated natural photoperiod than in those exposed to the summer-solstice hold photoperiod (16 February \pm 9 days versus 19 December \pm 6 days; $P<0.001$ ). Thus, the period of reproductive activity in Galway ewes exposed to summer-solstice hold photoperiod was shorter than that of ewes maintained on the simulated natural photoperiod (Table $2 ; P<0 \cdot 01$ ).

There was a breed difference in timing of the reproductive season of ewes maintained on simulated natural photoperiod in Expts 1 and 2. In Finn ewes, the onset of oestrous cycles was 6-7 weeks later $(P<0.001)$ and the end of cyclicity was $5-6$ weeks later $(P<0.05)$ than in Galway ewes (Fig. 2a, b, compare dates for ewes in simulated natural photoperiod). There was no breed difference in the duration of the reproductive season of ewes maintained on the simulated natural photoperiod (Table 2; $P>0.05$ ); but there was a breed difference in duration of reproductive activity under summer-solstice hold conditions, the breeding season being longer in Finn than in Galway ewes (Table 2; $P<0 \cdot 05$ ).

\section{Role of increasing photoperiod in onset of anoestrus}

Experiment 3: Finn ewes. The mean date of onset of anoestrus (end of oestrous cycles) in Finn ewes maintained on simulated natural photoperiod was $26 \mathrm{March} \pm 10$ days (Fig. 3a). This date was not significantly different $(P>0.05)$ from that of Finn ewes maintained on winter-solstice hold photoperiod (28 March \pm 10 days).

Experiment 4: Galway ewes. The requirement of increasing photoperiod to terminate the neuroendocrine breeding season of Galway ewes was evaluated by determining the time of the decline in circulating $\mathrm{LH}$ in ovariectomized ewes bearing Silastic oestradiol capsules (see Methods and Fig. 1). The end of the neuroendocrine breeding season (fall in $\mathrm{LH}$ ) was not different in ewes maintained on the simulated natural and winter-solstice hold photoperiods (Fig. 3b; 24 January \pm 6 days versus 16 January \pm 7 days, respectively; $P>0.05$ ).

Approximately 3 months after LH had fallen to baseline, the group of Galway ewes maintained on the winter-solstice photoperiod was subdivided, such that five ewes remained on that photoperiod and seven ewes were exposed to a summer-solstice photoperiod for 35 days beginning in 
(a)

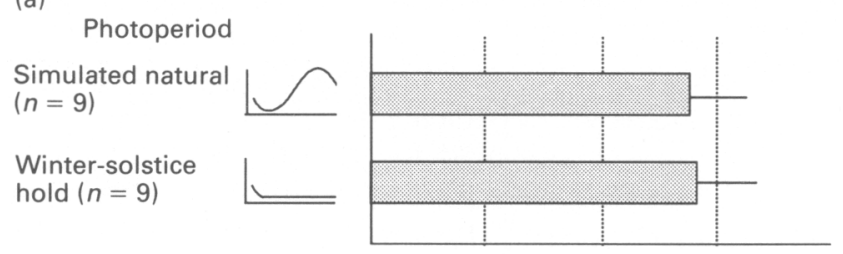

(b)

Simulated natural $(n=6)$

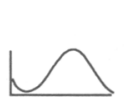

Winter-solstice hold $(n=14)$

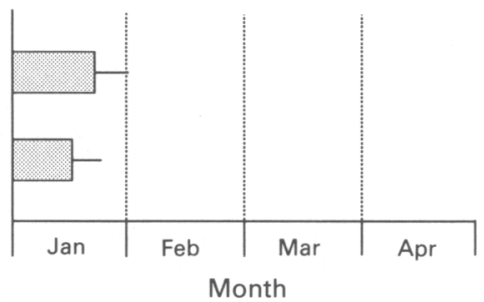

Fig. 3. Dates (mean \pm SEM) of end of reproductive activity (shaded bars) in (a) Finn (Expt 3) and (b) ovariectomized Galway ewes treated with continuous-release oestradiol capsules (Expt 4) and exposed to simulated natural or winter-solstice hold photoperiod $(8.5 \mathrm{~h}$ light: $15.5 \mathrm{~h}$ dark) from the winter solstice.

April (see Methods). This exposure to long days had a profound effect in that LH increased markedly in all ewes in late summer ( 5 September \pm 6 days; Fig. 4). In contrast, $\mathrm{LH}$ in ewes held on the winter-solstice photoperiod either increased later (two of the five ewes, 30 November, 8 January) or did not increase at all (three of five ewes) before the experiment was terminated in January, 405 days after onset of this photoperiod on the previous winter solstice (Fig. 4).

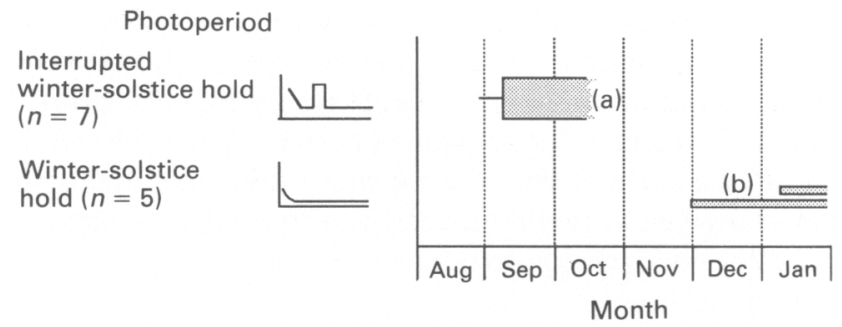

Fig. 4. Date (mean \pm SEM) of onset of reproductive activity (shaded bars) in ovariectomized Galway ewes treated with continuous-release oestradiol capsules (Expt 4), exposed to wintersolstice hold photoperiod interrupted with 35 days of summer-solstice photoperiod beginning 20 April or maintained on winter solstice photoperiod from the winter solstice; (a) data not collected after this date; (b) individual responses of the two of five ewes that became reproductively active shown for this treatment; the other three ewes did not become reproductively active before the end of the experiment.

\section{Discussion}

The current findings demonstrate that decreasing photoperiod from the summer solstice is not required to initiate the breeding season in either Galway or Finnish Landrace ewes. Further, the increasing photoperiod after the winter solstice is not required to signal the termination of the breeding season in either of these breeds. These conclusions are in agreement with those of similar 
studies performed on three other breeds including the Suffolk, Dorset Horn and Welsh Mountain (Worthy \& Haresign, 1983; Robinson \& Karsch, 1984; Robinson et al., 1985; Worthy et al., 1985). Thus, in each of the five breeds of sheep in which this type of study has been performed, there is no evidence that shortening days are required to initiate the breeding season, nor are lengthening days required to end it. This conclusion is consistent with the concept that both onset and end of the breeding season in this species are the consequence of an endogenous rhythm that is synchronized by the annual cycle of changing daylength (Robinson et al., 1985; Malpaux et al., 1988, 1989; Robinson \& Karsch, 1988; Karsch et al., 1989; Woodfill et al., 1991). We may postulate, therefore, that breed differences in timing of the seasonal reproductive transitions in ewes reflect genetic variation in either the characteristics of the endogenous rhythm itself or the photoperiodic synchronization of this rhythm.

One type of genetic difference in photoperiodic regulation suggested by our study pertains to the role of shortening days after the summer solstice in determining the duration of the breeding season. In Galway ewes, the shortening days of summer/autumn appear to be necessary to sustain a full-length breeding season; reproductive activity was curtailed when ewes were maintained on the summer-solstice photoperiod. In Finn ewes, the shortening days of summer/autumn appear to be unimportant in this regard; reproductive activity was not shortened when ewes of this breed were held on the summer-solstice photoperiod. This leads to the hypothesis that the difference in duration of reproductive activity in the two breeds reflects, in Finns, less dependence on decreasing photoperiod and more dependence on the endogenous rhythm and, in Galways, more of a requirement for decreasing photoperiod to sustain the breeding season. In the light of this hypothesis, it is of interest that the breeding season in Finn ewes held on the summer-solstice photoperiod was longer than that of Galway ewes maintained in the same photoperiod, suggesting a genetic difference in the duration of the endogenously generated reproductive season in these two breeds.

When the present study was designed, the temporal relationship between the annual photoperiodic cycle and the breeding season of Galway ewes had made the endogenous rhythm seem likely as a primary driving force of reproductive transitions, because the breeding season of Galway ewes in a natural photoperiod was known to begin when daylength is relatively long (early September) and end when daylength is still relatively short (mid-February). In Finn ewes, however, the onset of the breeding season was known to be forestalled until late October when photoperiod is relatively short, and the onset of anoestrus to be delayed until later in the spring when photoperiod is relatively long. This relationship between photoperiod and reproductive activity in Finn ewes had made photoperiodic drive of the seasonal transitions seem a more likely possibility for this breed. Our findings, however, show this is clearly not the case. Despite the 'delayed' breeding season in the Finn ewes, the endogenous rhythm can still account for the generation of seasonal reproductive transitions in this breed.

Apart from genetic differences in photoperiodic synchronization of the reproductive rhythm, there may be differences among breeds in the role played by other environmental factors in timing the reproductive transitions. In the present experiments, the duration of reproductive activity in Galway ewes maintained on simulated natural photoperiod was similar to that observed outdoors. The average duration of reproductive activity in Finn ewes on simulated natural photoperiod (154 days) was, however, considerably shorter than that reported in natural photoperiod (224 days). In recent studies, evidence has been presented that social cues derived from other sheep contribute to sustaining the breeding season for its full duration (Sunderland et al., 1990). It would be of interest to test the hypothesis that Finn ewes are more susceptible than Galway ewes to the influence of such non-photoperiodic factors.

A working hypothesis for photoperiodic synchronization of the circannual reproductive rhythm of Suffolk ewes has been proposed by Malpaux et al. (1989). According to this hypothesis, lengthening photoperiod between the winter and summer solstices synchronizes the endogenous rhythm; the long days around the summer solstice forestall the onset of reproductive activity until the autumn; and decreasing photoperiod after the summer solstice prolongs the breeding season for 
its full duration. Our present findings support this hypothesis and extend it to accommodate genetic variation among breeds. As concerns the postulated role for increasing daylength, our findings show that the breeding season begins synchronously and at the normal time in Finn and Galway ewes deprived of decreasing photoperiod after the summer solstice. This supports the hypothesis that reproductive onset in autumn is timed, in large measure, by the lengthening days experienced before the summer solstice. Further support for this view is provided by our findings, in Expt 4, that the breeding season was greatly delayed (or did not occur during the experiment) when Galway ewes were deprived of any increase in photoperiod after the winter solstice, but that a synchronous reproductive onset in late summer could be reinstated by exposure to 35 long days in mid-spring. Concerning the role of decreasing photoperiod, the current findings support the hypothesis that shortening days after the summer solstice provide a signal to sustain the breeding season in Galway ewes. This role of shortening photoperiod, however, may not be relevant for all breeds, as the reproductive season was not shortened in Finn ewes deprived of decreasing daylength after the summer solstice.

We found that two breeds of sheep that exhibit a difference in timing of their seasonal reproductive cycle do not require shortening photoperiod after the summer solstice to initiate the breeding season, and do not require lengthening photoperiod after the winter solstice to precipitate reproductive arrest. Our results are consistent with the conclusion that both breeds use an endogenous reproductive rhythm to generate the seasonal reproductive shifts. We suggest that genetic differences in the timing of the breeding season reflect a difference in photoperiodic synchronization of this rhythm. Although further studies are needed to delineate the specific variations in this photoperiodic regulation among breeds, our findings suggest that one such difference relates to the requirement for short days to sustain the breeding season for its full duration.

We wish to thank N. Hynes, G. Marr and G. Claffey for laboratory assistance; P. Duffy, F. Griffith and S. Sunderland for assistance with the animal experimentation; B. Malpaux, S. Moenter, N. Wayne and C. Woodfill for help in design of the study; and G. Niswender and Clonatech Ltd, Paris, France, for antibodies. This work was supported by University College Dublin in Ireland and NSF (INT-86-08943) in the USA.

\section{References}

Grubb, P. \& Jewell, P.A. (1973) The rut and the occurrence of oestrus in the Soay sheep on St Kilda. Journal of Reproduction and Fertility Supplement 19, $491-502$.

Hafez, E.S.E. (1952) Studies of the breeding season and reproduction of the ewe. Journal of Agricultural Science, Cambridge 42, 189-265.

Hanrahan, J.P. (1986a) Galway selection flock. An Foras Taluntais, Animal Production Research Report, 1986, pp. 80-81. An Foras Taluntais, Ireland.

Hanrahan, J.P. (1986b) Selection of ovulation rate in Finn sheep. An Foras Taluntais, Animal Production Research Report, 1986, p. 80. An Foras Taluntais, Ireland.

Hanrahan, J.P. (1990) Selection for improved reproductive performance of native sheep. In Small Ruminants Research and Development in the Near East,pp. 9-19. Ed. A. M. Aboul-Naga. Proceedings of a workshop held in Cairo, Egypt, 2-4 November 1988.

Hauger, R.L., Karsch, F.J. \& Foster, D.L. (1977) A new concept for control of the estrous cycle of the ewe based on the temporal relationship between luteinizing hormone, estradiol and progesterone in peripheral serum and evidence that progesterone inhibits tonic LH secretion. Endocrinology 101, 807-817.
Karsch, F.J., Dierschke, D.J., Weick, R.F., Yamaji, T., Hotchkiss, J. \& Knobil, E. (1973) Positive and negative feedback control by estrogen of luteinizing hormone secretion in the rhesus monkey. Endocrinology 92, 799-804.

Karsch, F.J., Robinson, J.E., Woodfill, C.J.I. \& Brown, M.B. (1989) Circannual cycles of luteinizing hormone and prolactin secretion in ewes during prolonged exposure to a fixed photoperiod: evidence for an endogenous reproductive rhythm. Biology of Reproduction 41, 1034-1046.

Malpaux, B., Wayne, N.L. \& Karsch, F.J. (1988) Termination of the breeding season in the Suffolk ewe: involvement of an endogenous rhythm of reproduction. Biology of Reproduction 39, 254-263.

Malpaux, B., Robinson, J.E., Wayne, N.L. \& Karsch, F.J. (1989) Regulation of the onset of the breeding season of the ewe: importance of long days and of an endogenous reproductive rhythm. Journal of Endocrinology 122, 269-278.

Niswender, G.D., Midgley, A.R. \& Reichert, L.E. (1968) Radioimmunologic studies with murine, bovine, ovine and porcine luteinizing hormone. In Gonadotropins 1968, pp. 299-306. Ed. E. Rosemberg. Geron-X Inc., Los Altos, CA.

Downloaded from Bioscientifica.com at 04/26/2023 10:01:01AM via free access 
Niswender, G.D., Reichert, L.E., Midgley, A.R. \& Nalbandov, A.V. (1969) Radioimmunoassay for bovine and ovine luteinizing hormone. Endocrinology 84, 1166-1173.

Oldham, C.M., Martin, G.B. \& Knight, T.W. (1978/1979) Stimulation of seasonally anovular merino ewes by rams. I. Time from introduction of the rams to the preovulatory LH surge and ovulation. Animal Reproduction Science 1, 283-290.

Quirke, J.F. \& Hanrahan, J.P. (1985) Breed differences in the breeding season in sheep. In Endocrine Causes and Seasonal and Lactational Anestrus in Farm Animals, pp. 29-43. Eds F. Ellendorff \& F. Elsaesser. Martinus Nijhoff, Dordrecht.

Quirke, J.F., Hanrahan, J.P., Loughnane, W. \& Triggs, R. (1986) Components of the breeding and nonbreeding seasons in sheep: breed effects and repeatability. Irish Journal of Agricultural Research 25, 167-172.

Robinson, J.E. \& Karsch, F.J. (1984) Refractoriness to inductive day lengths terminates the breeding season of the Suffolk ewe. Biology of Reproduction 31, 656-663.

Robinson, J.E. \& Karsch, F.J. (1988) Timing the breeding season of the ewe: what is the role of daylength? Reproduction Nutrition Development 28(2B), 365-374.

Robinson, J.E., Wayne, N.L. \& Karsch, F.J. (1985) Refractoriness to inhibitory daylength initiates the breeding season of the Suffolk ewe. Biology of Reproduction 32, 1024-1030.

Ronayne, E. \& Hynes, N. (1990) Measurement of plasma progesterone concentrations by extraction and nonextraction radioimmunoassays. Irish Journal of Agricultural Research 29, 109-115.

Siegel, S. (1956) Nonparametric Statistics for the Behavioural Sciences, pp. 116-127, 184-193. McGraw Hill Book Co. Inc., New York.
Sunderland, S.J., O'Callaghan, D., Boland, M.P. \& Roche, J.F. (1990) Social cues can alter the timing of reproductive transitions in ewes. Journal of Reproduction and Fertility Abstract Series 5, abstract 45.

Wayne, N.L., Malpaux, B. \& Karsch, F.J. (1989) Social cues can play a role in timing onset of the breeding season of the ewe. Journal of Reproduction and Fertility 87, 707-713.

Wayne, N.L., Malpaux, B. \& Karsch, F.J. (1990) Photoperiodic requirements for timing the onset and duration of the breeding season in the ewe. Journal of Comparative Physiology, A 166, 835-842.

Wheeler, A.G. \& Land, R.B. (1977) Seasonal variation in oestrus and ovarian activity of Finnish Landrace, Tasmanian Merino and Scottish Blackface ewes. Animal Production 24, 363-376.

Woodfill, C.J.I., Wayne, N.L., Brown, M.B. \& Karsch, F.J. (1990) Not all photoperiodic cues can synchronize the annual reproductive cycle. Biology of Reproduction 42, Supplement 1, abstract 183.

Woodfill, C.J.I., Robinson, J.E., Malpaux, B.M. \& Karsch, F.J. (1991) Synchronization of the circannual reproductive rhythm of the ewe by discrete photoperiodic signals. Biology of Reproduction 45, 110-121.

Worthy, K. \& Haresign, W. (1983) Evidence that the onset of seasonal anoestrus in the ewe may be independent of increasing prolactin concentrations and daylength. Journal of Reproduction and Fertility 69, $41-48$.

Worthy, K., Haresign, W., Dodson, S., McLeod, B.J., Foxcroft, G.R. \& Haynes, N.B. (1985) Evidence that the onset of the breeding season in the ewe may be independent of decreasing plasma prolactin concentrations. Journal of Reproduction and Feritity 75, 237-246.

Received 22 July 1991 